\title{
9 Soul (and Spirituality)
}

\author{
...over the city \\ the television antennae rise \\ like crucifixions without Christ \\ Yevgeny Yevtushenko
}

I have spoken of the passions, predilections, and preoccupations of Americans; now to address the subject of their official, chronic, national disease - loneliness. All our meanderings from reason, from wholeness, from sense, and sensibility, stem from that mother plant; at the heart of this sprawling semi-continent is a barrenness, a sterility of spirit, a void, whose depths may not be plumbed by preacher, psychologist, or pundit. A mass-society it may be, but nowhere is its unit atom more cut off, more severed, more removed from the roots of his social being, thrown up against himself, to struggle through life, in a more alien, unfriendly, inhospitable, environs. Material success is the only touchstone, competition the only rule, sink or swim, the only philosophy, of life.

Man is born free, wrote Rousseau, but everywhere he's in chains; here, we are held in thrall not by the chain, the rope, or the vice, but by the smiting of them, by the cutting off, by the drifting loose. We are Adrift, finding temporary moorings in casual relations, family, friends, and co-workers, but finding all of them subverted by (our own) selfishness, competitiveness, and treachery; they are there, still, but only as transient breaches of the overpowering sense of abandonment, loss, and privation. So when Kojak says, in that old tv series, sucking on a lollipop, 'So who loves you, baby?', we know the answer, and it echoes deep inside.

Social chains can stultify, but they can also succor, relieve, and enhance, life; the Somali herdsman knows not loneliness, nor boredom, neither does the Mongolian tribesman, nor the Afghan clansman, deeply enmeshed in the seamless webs of kinship, religion, and community. For thousands of years, in hundreds of social formations the world over, social life has borne these strong, affective, ascriptive, ties; binding each to each, and each to all, with a cohesion all but incorruptible; the market as a divisive device still held in check, bound by rule, chained by obligation, subordinate to custom; the demon of self-interest, like Prometheus, strapped securely in chains of social responsibility. This was before the great capitalist revolutions, of the sixteenth and seventeenth century, rudely sundered the ties of traditional society, making of fiefs a nation, of peasants a proletariat, and of the world, a market.

Self-provisioning, by far the rule of the social economy, in all societies (barring the meretricious vanities of rulers needing to be met by purchase, or purloin, of exotica) was disrupted radically and irreversibly; the greed of a few, merchants and masters, now preyed upon the needs of the many; the road to a world market, to anonymity as producers and consumers, to dependency on impersonal, external, forces was laid momentously for us all by an admixture of force, fraud and attrition. 
Although Americans have seen small farms swallowed by agro-business, small scale production, trade and crafts, gulped down by corporations, other than Native Americans, they have no real, direct historical memory of a village economy torn apart by the ravages of commerce and gain. A sense of history is stronger in societies where history has meant the destruction of a way of life; India is a modern, capitalist, country, but Indians can recall the values of a pre-capitalist orientation, if only because their culture and folk-lore is still a rich source of memory of the bygone era. Indeed, in case of many tribal populations in India, the primal dispossession is still in process of being enacted, in the early twenty-first century.

And Memory breeds near-certain resistance - myths, fables, and facts, of history being brought in to stave off the depredations of commerce, in favor of communal controls, traditional rights, and social responsibilities (in Britain, for instance, this memory of a social compact is enshrined both in classical Toryism - indeed Toryism is very different from American free-market ideology; for all her triumphs, Margaret Thatcher never won over the Church of England to her right-wing radicalism - and in labor activism, that at least offer token resistance to the more brazenly anti-social policies of corporate capital). In the near-desolate foothills of the Himalayas, in northern India, commercial developers, and their government/World Bank backers, out to turn living forests into timber revenue, ran unexpectedly into the protest of peasant women who threw their bodies in line of the bulldozers and chainsaws by 'hugging the trees', refusing access to the lumber-jacks, in a long campaign that finally resulted in victory over the Modernizers.

To the disbelief of a cynical world, largely (but only formally) uneducated village women were showing greater concern for environmental protection, for balance in the ecochain, for the unity of life, than the World Bank, or the Government of India. The 'Chipkos', as they are known, are now recalled as international stars of the Green Movement, and justly so, for they showed a contemptuous world that little people, ordinary folk, can care about big issues and make a big difference, if so resolved; that we can, impotent and small as we may be, still push for sanity, for decency, for wholeness - and succeed.

But where shall we, in America, get our memory from, except vicariously, borrowing from others? We could borrow it from the plight of the Native Americans, but they are no part of the body politic, and, outside of a hip fringe, the saga of the fall of the 'Indian' is drowned in the tawdry make-believe of cowboy movies. How shall we get the measure of what we have forfeited when our only memory is that of the system we presently live in? Who shall sing to us, by campfire and starlight, of a world on the wane, of a way of life lost, of the end of an era? About as close as we can get is Grizzly Adams, and his mock tv adventures, if not the hyped up adventures of Davy Crockett of another, bygone era.

Failing, therefore, to have any concept of an alternative, we have to assume that life is like it is, here and now, and has always been so; we may instinctively know that it is worse than it has ever been, and getting badder every day - but it is still not suf- 
ficient to get us stirred, stimulated, roused, awakened. Misreading our own history, we glibly misread that of others; and yet human history (whose inherent variety we are now bent upon obliterating) is a laboratory not only of misdeeds and wickedness, but also of benign, indulgent, and cordial forms of social life, and social subsistence, of gentle adaptations to nature, of simplicity, of conviviality, of grace.

Our ideology teaches us only contempt for other cultures, for 'lower forms of life', as we see them, despite all our mock deference to cultural pluralism; we see the Masai of Kenya, captured perhaps in a centerspread in the National Geographic, and we behold only poverty, and material scarcity; we see Australian Aboriginals, and we judge them hopelessly deprived (and depraved) of creature comforts, the boons of 'civilization'; we see peasants in Mexico, and we recoil in distaste for their plebeian ways; we see the desert bedouin on a camel, and we laugh at these, awkward, gangly, 'camel jockeys' - all of these images reinforcing only our own innate sense of superiority. Not for a moment do we ever wonder whether these peoples, closer to their ancient histories than we are, have anything to teach us at all about adaptation, about conservation, about values, about the ends of life.

The material yardstick suffices to condemn the non-commercialized world to barbarism; we have lost all other yardsticks - but they haven't. And, in point of fact, aside from the obvious richness of family, custom, and sentiment, in their cultural make-up relative to us, these wretched of the earth are also quite plainly more affluent than us (except when we rob and defraud them, as we have, through centuries of colonization, of their traditional means of provision) in material terms as well, remembering that real affluence is, always, a matter of resources exceeding needs. Better still, unlike us superior beings, they have not dissolved the ozone layer, or contributed to the greenhouse effect, or despoiled the rainforest, or depleted the species, animal and human, poisoned the air and water, built gulags, massacred by the millions, and made parts of the earth radioactive forever.

Most of all, they have yet retained the essence of social being, carrying it in their bones, as it were; steeped in affections, sentiment, caring, co-operation, and goodwill. Mormons in Utah are proud of their 'family values', which are quite exceptional, given national norms in this regard - imagine their consternation when a recent convert from Mali, just come in from Africa, talked to them, on public radio, of his great sadness at seeing grandparents, and the elderly generally, in Utah, neglected, segregated, and shunted into old folk's homes. It came as a genuine shock to them to be so upbraided, fancying themselves to be, if somewhat smugly, staunch upholders of old-fashioned family traditions; but moral standards are relative only to what we know, see, and remember; the two-generational family had become the norm even in Mormon Utah - not so, yet, in Mali.

We know not what we have lost, for we are lost ourselves in this great arid, industrial, wasteland; we are lost, for becoming part of the great ideology that offers us only the material slide rule in all measurements, public or private; for using only income as the touchstone of success and failure, public or private; for relying only 
on enhancement of per capita commodity production as our trusty index of progress. But Income, as the nearest accountant will aver, is only one side of the ledger; what of the Costs? What do we pay, as daily fare, in communities lost, in families divided, in ecospheres destroyed, in health, security, and sanity enfeebled, in control over our lives yielded?

The world rushes to us now, driven by greed insatiable, blitzed by the enormous payoffs of capital-rich America: the money, the magic, and the madness; the hustle, the hype, and the hoop-la - of industrial rhythms. The costs will only creep up on them slowly, behind their backs, hardening their arteries, stiffening their sinews, congealing their blood, if they stay long enough; and then they too, one day, much like us, will yearn for the ease of non-industrial rhythms, for harmony, for fellowship, for warmth, for peace, for concord, for rest, repose, and reflection.

Though we have steadfastly catered to the lowest instincts possible, levelling human propensities, and abasing human relations, we still long for nourishment of the soul, for spirituality; how can we not? We are human yet, no matter how far debauched, or dissolute; and so, as and when we can afford it, we turn away from the hum-drum and the dross, the barren and the bought-out, hoping to find something richer, more durable, than teflon. And, at a pinch, as staple and stand-by, there's church and religion, for the system is both mindful and provident; indeed, there are more practicing religions, sects, cults, and denominations, in America than anywhere else (like all supermarkets in America, the divine supermarket is overstocked as well, and has been from the start; as sanctuary for religious minorities, America has hosted numerous persuasions from its early history; from Puritans, to Quakers, to the Amish, the Hutterites, the Rappites, the Inspirationists, the Shakers, and so on; later on, the Mormons, Christian Scientists, Jehovah's Witnesses, all offshoots of Classical Christianity; and still later, sects too many to name, from the Children of God to the Moonies). Religions offer us (an imagined) community, Here, and in the Afterlife: we would love to avail of its touted restitutions here and now, but, nothing if not patient, we're quite ready to settle for the Promise of the afterlife - and so we subscribe, and pay, and donate, for the word of god, for the kingdom still to come (hope is given us only for the sake of the hopeless, as Walter Benjamin had it: church-going is even more popular in the ghetto). Half a dozen tv evangelists, from Pat Robertson to the Swaggarts, Bakkers, etc., have depended on this material show of goodwill of ordinary people, to support their ambitious religious enterprises - for organized religion is a business, like anything else, in America; a non-profit business (although that's mostly semantics), but a business all the same, whose balance sheets would reveal flows of income and expenditures, assets and equities, that any moderate-sized corporation might envy (the most impressive looking real estate in Salt Lake City, naturally, are the substantial properties owned by the Latter Day Saints).

The older, and more established, churches in America have long since given over to rote and ritual, bureaucracy and routine, integrated fully with commercial society (including, of course, its ruling prejudices; a black Christian minister tried, but could 
not enter ex-president Jimmy Carter's little church in Georgia - so much for the love of Jesus in god's own country), their functions being largely ceremonial: sunday churchgoing being just that, and nothing more - the salvation offered being neither costeffective, nor very credible.

Outside of organized religions are the spiritual mendicants, of all varieties, from the world over; the Bahai's, the Sufis, the Zen masters, and the host of irrepressible Indian Gurus, from the (late) Maharishi Mahesh Yogi to the Meher Baba, who usually pooled in a more literate following seeking not godhead, but guidelines for life - and getting it, if at exorbitantly high prices. (The late) Bhagwan Rajneesh, the Indian Guru, who set up in Antelope, Oregon, pulled in \$150 million in just four, tumultuous, years; and he was just one, among many. The media that dare not ridicule organized religion in America (nor publish their financial statistics), being one of the pillars of the establishment, and an estate in its own right, goes to town on the spiritualists, and the gurus, armed with both malice and ignorance, seeing a greater threat there, instinctively, to 'American values' than in all the ministries of Christ on the continent. True, most, but not all, such spiritualists are mercenary, even venal, but that's only to say they charge a lot; not that they don't deliver what's promised.

Our spiritual starvation is so acute, even the simplest words of ordinary wisdom touch us deeply; our artificiality so banal, the slightest mark of authenticity impels us to worship; our coldness and indifference so deep, that but a smidgeon of love and warmth moves us to tears.

I stood in a lecture hall in California, years ago, listening to an Indian Guru speak of the (forgotten) arts of life to a large audience of obviously affluent people (judging by the aspect of their cars in the parking lot). He spoke of the simplest, most trivial, things - drinking a glass of water, for instance -, but in such ecstatic terms as to bring home the mystery of life, and the joy of unfiltered sensuality, warmth, and togetherness, in this enigma of a universe. He spoke softly of our petty envies, aversions, and affectations; of how we weave, by our own arts, so much that is synthetic, so much that is silicone, so much that is self-destructive, in our lives.

I looked around, bemused: lawyers, doctors, and stockbrokers - Porsche-driving, lap-top using, Martini-guzzling Americans as they were, were listening in rapture, spellbound, mesmerized, bewitched - a few even crying, for seeing but the barest hint of a glimpse of what we are robbed of, of what is possible, of what can be. Of course, they would all go back to their Porsches, laptops, and their Martinis, soon enough; but not without their eyes opened, their sensitivities stimulated, their spirituality stirred. The toad that looks at heaven, and sees no heaven there, is a breed apart from one that has seen and returns to earth: of necessity, and with a laden heart.

There is a great void at the heart of America; and it is spiritual (whether we are aware of it or not). It's a void that we attempt to fill with sex, with tv, with religion, with drugs, with food and drink. But it is not to be filled that way; for it is not of the senses at all, nor of the mind. The dimensions to our perceptions, our ways of knowing, are many: there's the intellect, driven by reason, cold, austere and uncaring; 
there's instinct, warmer in inspiration, closer to flesh and blood, driven by our genetic memory; then there's intuition, which lies beyond mind and body, part of our collective being/consciousness, capable of revealing the unity of the whole in one, blinding, flash of revelation.

Civilization tames, sometimes even extinguishes, our instincts; our intellect is poisoned by the selfish calculations of material rationality; only the intuitive domain is free of any such usurpations, from social controls, from ideological manipulations. It is intuition that records, registers, and retains our real intimations of loneliness, unhappiness, and despair, even as we go about effecting compromises, denying our real needs, suppressing our desires - and settling for less. There is, somewhat quixotically perhaps, a 'Happy Planet Index' that provides a means of broad assessment between nations across the globe: the US ranked $105^{\text {th }}$, despite topping the GDP chart.

Of all the living cultures in the world, we lack soul the most: it's that critical deficiency that makes everything taste rancid, unsavory, and unwholesome, crippling our reservoir of sensibilities, and turning every ordinary human interaction, from a visit to the grocery store, to a trip to the doctor's, into a stand-off fraught with anxiety, insecurity, and unpleasantness. Coldness, indifference, hostility, and abrasiveness, lend unnecessary friction to our most casual encounters, transmuting them into debilitating skirmishes that leave one or other party with a stinging sense of loss: of dignity, of self-respect, and confidence (I have a friend who won't even answer the phone, lest it ruin her day!).

At any social event in traditional India, by contrast, even perfect strangers will greet and offer other perfect strangers warmth, cordiality, and amity, in the supreme effort, but made effortlessly, to validate each other, to bolster each other, to assure, comfort, and support. The interaction may oft, if not always, be syrupy, insincere, even false; but it tries to do good: you want people who merit your attention (or who find you meritorious for attention) to leave feeling warmed, encouraged, fostered, and fortified. The social terrain need not be a vicious minefield of one-upmanship, of stark utility, or of glacial aloofness, which can only destroy weak personalities, and induce neurosis in strong ones. When moved, Indians run to friends and family, the way Americans run to their psychiatrists, therapists, and counselors: so, whatever happened to our friends and family?

I wondered at first at the ubiquity of humor in America, such a striking, welcome, characteristic to the outsider looking in, reinforcing the initial 'nice guy' image of the average American; then I realized that it stemmed from the incredible tensions of American society - it is, like social drinking, a stress-relieving mechanism par excellence, even though in its practice (in its insult-affrontery-barb variants), it may actually raise such levels inordinately. The social itself is a great, natural, rousing, turn-on (think of the high-flying hysteria of a crowd at a stadium), mood-booster, and antidepressant; but, when we let the ice set in, the iron enter, and the ties decay, we are forced to turn to hugely unpromising, artificial, spasmodic, stimulants. 
Repressive individualism, of the American kind, in Hobbesian fashion, is premised upon the notion that the normal state prevailing between two (male) humans is one of war (aggression, anger, etc.), only to be mollified by the (temporary) meltdown provided by the dry wisecrack and the equally dry Martini: yet real civilizations have flourished for thousands of years without need for either. Civilization, unlike society, is about fellowship and fraternity, hospitality, and tolerance; not conflict, competition, advancement, and social climbing - the laws of nature need not be, must not be, the preferred Exemplar for social relations.

Our loneliness is the unsplendid gift of our (un)social economy, enforcing radical distance, separation, and atomism; but, we too, on our part, internalize these systemic requirements and make them our own. We strive for difference and differentiation; we keep up, and compete, with the Joneses, wanting only to surpass them. We scorn defeat, and shun the fallen; we worship success, and idolize the successful. We stratify, classify, define, and categorize, each other, materially, socially, physically. We are hierarchical, snobbish, jealous, and hostile; we are trampled, we are ready to trample; we are injured, we're ready to do injury; we are wronged, we're ready to do wrong.

We are narrow, selfish, petty, single-minded, intolerant, prejudiced, and violent; architects of the very beds we lie upon, of the traps that ensnare us, of the demons that devour us, of the very waves that engulf us, of the ambitions that destroy us. We are both victor and victim, hunter and hunted, observer and observed, deceiver and deceived, oppressor and oppressed, root cause and rank effect. The very rationality we rely upon (the 'objective, dispassionate' routine), the critical temperament it entails, the summary judgments it provokes, is bitterly divisive, rupturing, and belligerent; we dispense reason without sympathy, criticism without tolerance, and judgment without compassion (and ask not who tolls the bell; not one of us, whose hands are not sullied).

But empathy obviates criticism; compassion preempts censure; and caring dissolves distance (the three ugliest words I have heard in America are the all too familiar refrain: 'I don't care'; I'll wager they are heard more often in America, on a daily basis, than in the rest of the world taken together. Even newcomers from more complaisant cultures pick up the attitude fast). We brought the moon closer, at staggering cost; but are we any more intimate with our own selves, with each other?

Nowhere on earth are people more ready to take offence, feel slighted, snubbed, and set upon, at the airiest provocation; we are all brewing cauldrons, smoldering furnaces, of resentment, pique, ire, spite, and wounded pride. You can ride the buses all day, and not hear a kind word, witness a generous impulse at work, or observe one uplifting act of untempered altruism. Like feuding barons, we mark our territories, draw boundaries, and set up fences ('good fences make good neighbors'); you may not trespass on your neighbor's time, trust, confidence, charity, or bounty. We are all, as the truckers' decals say, 'Insured by Smith \& Wesson'; insured by our sullen bigotries, insulated by our thick skins, inured by our own harshness, sequestered by our own severity. 
The social instinct is become a commercial instinct, a killer instinct, an instinct honed in only to blood and gold; there is no idle conversation, no wasted breath, no aimless word or gesture; all is economized, privatized, stored away, deferred to point optimal. Nothing is to be given away free.

I remember a senior colleague of mine from India who visited New York as a Fulbright scholar resident at Columbia University. A month prior to his coming, he had warmly played host to a Faculty member from Columbia, on a research visit to India; he had roomed and boarded him, wined him, dined him, introduced him to all and sundry, including important Government officials, of some use to the visiting American, looking upon him - as feckless cultural primitives tend to do - affectionately, as a friend, a brother, a member of his own family. Now, he was coming to New York, and entertaining great hopes of renewing his colleague's fellowship, friendship, and association.

By coincidence, his friend's office happened to be situated on the same floor, and he rushed over, in child-like excitement, knocked on the door, and stepped in, chock full of greetings. His ex-guest of but weeks ago, who had spent eighteen hours a day with him straight on for a month, greeted him now with surprise and coolness, not a little peeved at being disturbed from his preoccupations; then, pulling out an engagement book, he said, 'Sorry I'm busy now, but let's do a lunch next month' New Delhi was one trip; New York, another. My colleague was an elderly, emotional, warm-blooded, deeply caring man; he came to me, told me the story, and cried, heartbroken. Having repeatedly tasted rank treachery myself, I could only feel for him and his gnawing sense of betrayal and abandonment. And I was reminded of some not too ancient Indian history, when the British, received graciously at court as friends, guests, and welcome visitors, turned around and stuck a dagger deep into the heart of their hosts, a dagger that remained in place, stained and bloody, for some two hundred years (Albion was not called perfidious, for nothing). Who shall erase those scars, or repair those wounds: what philanthropy can forget or forgive them?

Nature repairs her ravages, wrote George Eliot; and if we, the human inheritance of creation, are not wary and mindful, we too shall disappear as a tiny spark in the comet dust of infinity. We need, as masters of the universe now, to take pause and reflect upon the world we have unbuilt, the traps we have laid, the spaces, inner and outer, we have mined. The celebration of the great American way, in this past American century, has been overly long, gaudy, and deafening; but the Carnival is now come to an ominous pass, where others, heady with our example, are took to the field, ready to repeat our errors, omissions, and forfeitures, with even greater zeal than our own.

The demons we have unleashed will, inevitably, return to haunt us, imposing a servitude even more oppressive than the one we know today; we must be undone, and we must do it ourselves, for ourselves - and for others. For official ideology, the dominant ethos, is one thing, and human values, another - subsisting, dormant, and camouflaged, on the inside, waiting to be raised, revived, resuscitated. No matter how 
dastardly, or infamous, the ruling fashions, whether of Hitler's Germany, Reagan's America, or George Bush's New World Order, there are always shades of compunction and conscience, tints of contrition and remorse, and echoes of empathy and affection, hid deep within our inner selves. It is that touch of human nature that makes all the world kin!: it is the stuff that makes liars blush (inwardly, if not outwardly), and Macbeths lose their sleep - in all societies.

It is what enables questioning, criticism, and reproof, from Los Angeles to Tiananmen to Baghdad; it is the fount of all charity, of mercy, of pity, and compassion. It is that unborn, ever-abiding universal 'non-local' consciousness (the Brahman of Vedic philosophy) wherein we are all merged, sooner or later, into one. It is what makes hope possible, even in America, no matter how craven the capitulation, how cowering the surrender. And the time is surely ripe; for Rosemary is having a baby, here in America, be warned: though the world, at large, dare not sneer at her (indeed European civilization is on the same page as America in most regards) because: De Te Fabula Narratur it is of you (too) that the story is told. 